\begin{tabular}{|l|l|l|l|l}
\hline Int.J.Curr.Microbiol.App.Sci (2018) 7(10): 1235-1239 \\
$\begin{array}{l}\text { International Journal of Current Microbiology and Applied Sciences } \\
\text { ISSN: 2319-7706 Volume 7 Number 10 (2018) } \\
\text { Journal homepage: http://www.ijcmas.com }\end{array}$ \\
\hline $\begin{array}{l}\text { EXCELLENT } \\
\text { PUBLISHERS }\end{array}$
\end{tabular}

Original Research Article

https://doi.org/10.20546/ijcmas.2018.710.138

\title{
Targeted Yield Based Fertilizer Prescriptions for Brinjal (Solanum melongena L.) in Ultisols of Kerala, India
}

\author{
V.I. Beena, B. Bastin, R.P. Raji Mol* and P. Dey
}

AICRP on STCR, College of Horticulture, Vellanikkara, 680656, Thrissur, Kerala, India

*Corresponding author

\section{A B S T R A C T}

Keywords

STCR-IPNS, Ultisol, Ready reckoner, Brinjal

Article Info

Accepted:

10 September 2018 Available Online:

10 October 2018
To develop fertilizer prescription equations based on target yield for brinjal, a field experiment was conducted in laterite soils of STCR field, College of Horticulture, Kerala Agricultural University, Thrissur by using integrated plant nutrient management system on the basis of STCR approach. Soil test data, fruit yield and NPK uptake by brinjal were used for obtaining four important basic parameters viz., nutrients required to produce one tonne of brinjal (NR), per cent contribution of nutrients from fertilizers (\% CF), per cent contribution of nutrients from soil $(\% \mathrm{CS})$ and per cent contribution of nutrients from organic matter $(\% \mathrm{COM})$. The nutrient requirement of brinjal to produce one tonne of fruit yield was found to be $0.30 \mathrm{~kg} \mathrm{t}^{-1} \mathrm{~N}, 0.03 \mathrm{~kg} \mathrm{t}^{-1} \mathrm{P}_{2} \mathrm{O}_{5}$ and $0.58 \mathrm{~kg} \mathrm{t}^{-1} \mathrm{~K}_{2} \mathrm{O}$ respectively. The per cent contribution of nutrients from soil, fertilizer and FYM were 5.10, 8.51 and 0.02 for $\mathrm{N} ; 20.39,6.18$ and 0.02 for $\mathrm{P}_{2} \mathrm{O}_{5} ; 10.29,82.33$ and 0.15 for $\mathrm{K}_{2} \mathrm{O}$ respectively. $\mathrm{By}$ using these basic parameters, ready reckoner of fertilizer doses was prepared for varying soil test values and desired yield targets of brinjal for NPK alone and NPK with FYM.

\section{Introduction}

Irrational use of chemical fertilizers has caused irreparable harm to the fertility of soil as well as human health. The present day agricultural practices are relying upon the application of chemical fertilizers by neglecting the use of organic manures. Balanced fertilization has to be considered for maintaining soil health for sustainable use because indiscriminate and imbalanced use of fertilizers has already deteriorated soil health. Accordingly much attention is given to the integrated use of organic and mineral nutrition for meeting the economic needs of farmers as well as for sustainability in terms of productivity and soil fertility. Soil test based fertilizer recommendations result in efficient fertilizer use and maintenance of soil fertility. Targeted yield concept is based on quantitative idea of the fertilizer needs based on yield and nutritional requirement of the crop, per cent contribution of the soil available nutrient and that of the applied fertilizer (Ramamoorthy et al., 1967). This method not only estimates soil test based fertilizer dose but also the level of yield the farmer can achieve with that particular dose.

Brinjal, an important solanaceous vegetable is being widely cultivated in Kerala because of its climatological as well as soil suitability. 
The adhoc fertilizer recommendation for brinjal in Kerala is 75: 40: $25 \mathrm{~kg} \mathrm{ha}^{-1}$ of $\mathrm{N}$, $\mathrm{P}_{2} \mathrm{O}_{5}$ and $\mathrm{K}_{2} \mathrm{O}$, respectively (Package of Practices Recommendations, 2007). To develop an efficient fertilizer management strategy for desired target yield, inductivecum-targeted yield approach (Ramamoorthy et al., 1967) has been undertaken.

\section{Materials and Methods}

A field experiment with brinjal (var. Haritha) was conducted in AICRP - STCR field, College of Horticulture, Vellanikkara, Thrissur. A fertility gradient experiment was carried out using fodder maize (var. Co-1). The soil reaction was acidic. The available $\mathrm{N}$, $\mathrm{P}_{2} \mathrm{O}_{5}$ and $\mathrm{K}_{2} \mathrm{O}$ were medium. The soil belongs to the order ultisol. The experiment was laid out in three strips. Each strip was further divided into 24 plots of $2 \times 5 \mathrm{~m}$ size. The 24 plots in each strip were allotted with 20 treatment combinations and 4 controls. The FYM levels were super imposed in the treatment structure. The treatment structure was in such a way that each strip received all the treatment combinations. Each strip contained two control plots that received no FYM or fertilizers for brinjal. The remaining 22 plots of each strip received either FYM or fertilizer or a combination of both (Table 1).

The organic manure as per the treatments was applied in the plots along with the full dose of $\mathrm{P}$ and half doses of $\mathrm{N}$ and $\mathrm{K}$ as basal. The remaining $14^{\text {th }}$ of $\mathrm{N}$ and $1 / 2$ dose of $\mathrm{K}$ were applied 30days after planting and the remaining $\mathrm{N}$ was applied 2 months after planting.

The plants were uprooted carefully after harvest, cleaned and the fresh weight was taken and the yield was recorded and expressed as $\mathrm{t} \mathrm{ha}^{-1}$. The nutrient uptake was computed separately for the fruits and for the biomass (including stems, leaves and roots).
The plant samples were analysed separately for the contents of $\mathrm{N}, \mathrm{P}$ and $\mathrm{K}$ after harvest as per standard procedures as described by Piper, (1966). The total uptake of N, P and K were computed from the nutrient contents and dry weight of plant parts and expressed as $\mathrm{kg} \mathrm{ha}^{-1}$ as per standard procedures. The fertilizer prescription equations were developed based on the data of soil test values, fruit yield and the nutrient uptake by brinjal.

Plot-wise soil test data, fertilizers doses, yield and uptake were used for obtaining NR (nutrient required to produce one tonne of fruit yield), \%CS (per cent contribution of nutrients from soil), \% CF (per cent contribution of nutrients from fertilizers) and \% COM (per cent contribution of nutrients from organic manure), as per method described by Ramamoorthy et al., (1967)

Total uptake of nutrients $\left(\mathrm{kg} \mathrm{ha}^{-1}\right)$ in plot Nutrient requirement in

$\mathrm{kg} \mathrm{t}^{-1}$ of grain $(\mathrm{NR})=$

Grain yield $\left(\mathrm{t} \mathrm{ha}^{-1}\right)$ in plot

Total uptake of nutrients in Control plot $\left(\mathrm{kg} \mathrm{ha}^{-1}\right)$

Per cent contribution of nutrients from soil $(\% \mathrm{CS})=$ $\times 100$

Soil test values of nutrients in Control plot $\left(\mathrm{kg} \mathrm{ha}^{-1}\right)$

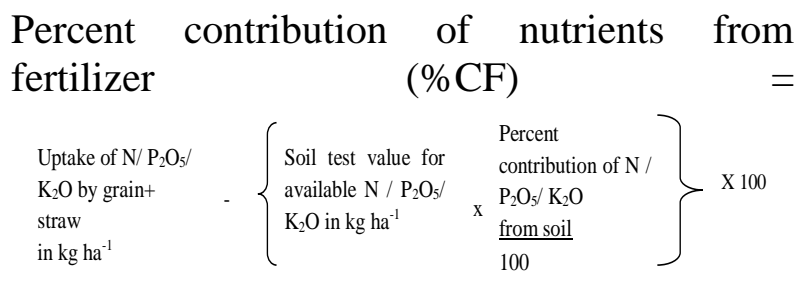

Fertilizer $\mathrm{N} / \mathrm{P}_{2} \mathrm{O}_{5} / \mathrm{K}_{2} \mathrm{O}$ applied in $\mathrm{kg} \mathrm{ha}^{-1}$

These parameters were used to develop equations for soil test based fertilizer recommendations for desired yield targets of brinjal under NPK alone as well as NPK plus FYM. 


\section{Results and Discussion}

\section{Soil available nutrients and fruit yield}

Fruit yield, nutrient uptake by brinjal and available major nutrients under different strips are presented in table 1. Maximum yield was obtained in $\mathrm{L}_{2}\left(9.6 \mathrm{t} \mathrm{ha}^{-1}\right)$ followed by $\mathrm{L}_{0}(8.2 \mathrm{t}$ $\left.\mathrm{ha}^{-1}\right)$ and the lowest in $\mathrm{L}_{1}\left(7.1 \mathrm{t} \mathrm{ha}^{-1}\right)$. Available $\mathrm{N}$ and $\mathrm{K}$ were highest in strip $\mathrm{L}_{2}$ (427 and $481 \mathrm{~kg} \mathrm{ha}^{-1}$ respectively) whereas the available $\mathrm{P}$ was highest in $\mathrm{L}_{0}\left(13.8 \mathrm{~kg} \mathrm{ha}^{-1}\right)$. The uptake of $\mathrm{N}, \mathrm{P}$ and $\mathrm{K}$ were highest in $\mathrm{L}_{2}$ (32, 4.6 and $64 \mathrm{~kg} \mathrm{ha}^{-1}$ respectively) followed by $\mathrm{L}_{0}\left(22,2.1\right.$ and $37 \mathrm{~kg} \mathrm{ha}^{-1}$ respectively) and $\mathrm{L}_{1}\left(19,2.1\right.$ and $37 \mathrm{~kg} \mathrm{ha}^{-1}$ respectively).

\section{Basic parameters}

Making use of the above data on fruit yield of brinjal, uptake of $\mathrm{N}, \mathrm{P}$ and $\mathrm{K}$, initial soil test values, and the doses of $\mathrm{N}, \mathrm{P}_{2} \mathrm{O}_{5}$ and $\mathrm{K}_{2}$ Oapplied, the basic parameters were computed. The basic parameters for developing fertilizer prescription equations for brinjal are: (i) nutrient requirement in $\mathrm{kg}$ per quintal of fruit (NR), (ii) per cent contribution from soil available nutrients (CS), (iii) per cent contribution from fertilizer nutrients (CF) and (iv) per cent contribution from organic manure $(\mathrm{COM})$.

\section{Nutrient Requirement (NR)}

The results emanated from the present investigation revealed that brinjal required $0.30 \mathrm{~kg}$ of $\mathrm{N}, 0.03 \mathrm{~kg}$ of $\mathrm{P}_{2} \mathrm{O}_{5}$ and $0.58 \mathrm{~kg}$ of
$\mathrm{K}_{2} \mathrm{O}$ for producing one quintal of brinjal fruits (Table 2). The data revealed that the order of $\mathrm{NR}$ was $\mathrm{K}_{2} \mathrm{O}>\mathrm{N}>\mathrm{P}_{2} \mathrm{O}_{5}$. The results were in accordance with the findings of Santhi et al., (2011) and Sellamuthu et al., (2015).

Per cent contribution from soil (CS), fertilizers (CF) and organic manure (COM)

The per cent contribution towards the uptake of $\mathrm{N}, \mathrm{P}$ and $\mathrm{K}$ from soil was 5.10, 20.39and 10.29 per cent respectively. Among the three nutrients, contribution of soil towards $\mathrm{P}_{2} \mathrm{O}_{5}$ was the high, followed by $\mathrm{K}_{2} \mathrm{O}$ and $\mathrm{N}$.

The per cent contribution of $\mathrm{N}, \mathrm{P}$ and $\mathrm{K}$ from fertilizer was $8.51,6.18$ and 82.33 per cent, respectively. The order of contribution of fertilizer towards $\mathrm{N}, \mathrm{P}$ and $\mathrm{K}$ was $\mathrm{K}_{2} \mathrm{O}>\mathrm{N}$ $>\mathrm{P}_{2} \mathrm{O}_{5}$. The per cent contribution of $\mathrm{N}, \mathrm{P}_{2} \mathrm{O}_{5}$ and $\mathrm{K}_{2} \mathrm{O}$ from organic manure (CFYM) was $0.02,0.02$ and 0.15 per cent, respectively. Among the three nutrients, organic manure contribution was more towards $\mathrm{K}_{2} \mathrm{O}$. The results were in line with the findings of Santhi et al., (2011) and Sellamuthu et al., (2015) who observed relatively higher contribution from both fertilizer and FYM towards $\mathrm{K}_{2} \mathrm{O}$ rather than $\mathrm{N}$ and $\mathrm{P}_{2} \mathrm{O}_{5}$.

\section{Fertilizer prescription equations under IPNS for desired yield target}

Soil test based fertilizer prescription equations for desired yield target of brinjal were formulated using the basic parameters and are furnished below:

Table.1 Treatment structure of complex experiment

\begin{tabular}{|c|c|c|c|c|}
\hline $\begin{array}{c}\text { Nutrient } \\
\text { levels }\end{array}$ & \multicolumn{2}{|c|}{ Fertilizer dose $\left(\mathbf{k g ~ h a}^{-\mathbf{1}}\right)$} & $\left.\begin{array}{c}\text { FYM } \\
(\mathbf{t ~ h a}\end{array} \mathbf{~}^{-\mathbf{1}}\right)$ \\
\hline 0 & 0 & $\mathbf{P}_{\mathbf{2}} \mathbf{O}_{\mathbf{5}}$ & $\mathbf{K}_{\mathbf{2}} \mathbf{O}$ & 0 \\
\hline 1 & 37.5 & 0 & 0 & 15 \\
\hline 2 & 75 & 40 & 12.5 & 30 \\
\hline 3 & 150 & 80 & 50 & -- \\
\hline
\end{tabular}


Table.2 Fruit yield, nutrient uptake and available nutrient status of brinjal in different strips

\begin{tabular}{|c|c|c|c|c|c|c|}
\hline \multirow{2}{*}{ Particulars } & \multicolumn{2}{|c|}{ Strip L $\mathbf{L}_{0}$} & \multicolumn{2}{|c|}{ Strip $\mathrm{L}_{1}$} & \multicolumn{2}{|c|}{ Strip $\mathbf{L}_{2}$} \\
\hline & Range & Mean & Range & Mean & Range & Mean \\
\hline Fruit yield $\left(\mathrm{t} \mathrm{ha}^{-1}\right)$ & $3.8-11.5$ & 8.2 & $4.5-10.8$ & 7.1 & $3.8-14.6$ & 9.6 \\
\hline N uptake $\left(\mathrm{kg} \mathrm{ha}^{-1}\right)$ & $12-43$ & 22 & $10-27$ & 19 & $23-44$ & 32 \\
\hline P uptake $\left(\mathrm{kg} \mathrm{ha}^{-1}\right)$ & $0.9-3.2$ & 2.1 & $1.0-4.4$ & 2.1 & $2.0-5.3$ & 4.6 \\
\hline K uptake $\left(\mathrm{kg} \mathrm{ha}^{-1}\right)$ & $24-65$ & 40 & $21-53$ & 37 & $46-108$ & 64 \\
\hline $\mathrm{KMnO}_{4}-\mathrm{N}\left(\mathrm{kg} \mathrm{ha}^{-1}\right)$ & $310-477$ & 412 & $285-470$ & 404 & $367-493$ & 427 \\
\hline Bray-P $\left(\mathrm{kg} \mathrm{ha}^{-1}\right)$ & $8.0-20.0$ & 13.8 & $7.0-18.8$ & 11.4 & $7.0-19.0$ & 10.2 \\
\hline $\mathrm{NH}_{4} \mathrm{OAc}-\mathrm{K}\left(\mathrm{kg} \mathrm{ha}^{-1}\right)$ & $252-534$ & 379 & $280-728$ & 454 & $336-616$ & 481 \\
\hline
\end{tabular}

Table.3 Basic parameters of brinjal experiment

\begin{tabular}{|c|c|c|c|c|}
\hline \multirow{2}{*}{ Nutrient } & \multicolumn{4}{|c|}{ Basic data } \\
\hline $\mathbf{N}$ & $\mathbf{N R}\left(\mathbf{k g ~ t}^{\mathbf{- 1}}\right)$ & $\mathbf{C S}($ per cent) & $\mathbf{C F}$ (per cent) & COM (per cent) \\
\hline $\mathbf{P}_{2} \mathrm{O}_{5}$ & 0.30 & 5.10 & 8.51 & 0.02 \\
\hline $\mathrm{K}_{2} \mathbf{O}$ & 0.03 & 20.39 & 6.18 & 0.02 \\
\hline
\end{tabular}

Table.4 Ready reckoner for brinjal with target yield of 25 and $30 \mathrm{t} \mathrm{ha}^{-1}$ with and without organic manures

\begin{tabular}{|c|c|c|c|c|c|c|c|c|c|c|c|c|c|c|}
\hline \multirow{3}{*}{\multicolumn{3}{|c|}{$\begin{array}{c}\text { Soil available } \\
\text { nutrients } \\
\left(\mathrm{kg} \mathrm{ha}^{-1}\right)\end{array}$}} & \multicolumn{12}{|c|}{ Fertilizer nutrient required $\left(\mathrm{kg} \mathrm{ha}^{-1}\right)$ for yield target of } \\
\hline & & & \multicolumn{6}{|c|}{$25 \mathrm{t} \mathrm{ha}$} & \multicolumn{6}{|c|}{30 ha $^{-1}$} \\
\hline & & & \multicolumn{3}{|c|}{$\begin{array}{c}\text { without organic } \\
\text { manure }\end{array}$} & \multicolumn{3}{|c|}{$\begin{array}{c}\text { with organic } \\
\text { manure }\end{array}$} & \multicolumn{3}{|c|}{$\begin{array}{c}\text { without organic } \\
\text { manure }\end{array}$} & \multicolumn{3}{|c|}{ with organic manure } \\
\hline $\mathbf{N}$ & $\mathbf{P}$ & $\mathbf{K}$ & $\mathbf{N}$ & $\mathbf{P}_{2} \mathbf{O}_{5}$ & $\mathbf{K}_{2} \mathbf{O}$ & $\mathbf{N}$ & $\mathbf{P}_{2} \mathbf{O}_{5}$ & $\mathbf{K}_{2} \mathbf{O}$ & $\mathbf{N}$ & $\mathbf{P}_{2} \mathbf{O}_{5}$ & $\mathbf{K}_{2} \mathbf{O}$ & $\mathbf{N}$ & $\mathbf{P}_{2} \mathbf{O}_{5}$ & $\mathbf{K}_{2} \mathbf{O}$ \\
\hline 100 & 6 & 100 & 29 & 0 & 5.75 & 0 & 0 & 0 & 46.8 & 0 & 9.3 & 0 & 0 & 0 \\
\hline 150 & 8 & 200 & 0 & 0 & 0 & 0 & 0 & 0 & 16.8 & 0 & 0 & 0 & 0 & 0 \\
\hline 200 & 10 & 300 & 0 & 0 & 0 & 0 & 0 & 0 & 0 & 0 & 0 & 0 & 0 & 0 \\
\hline 250 & 12 & 400 & 0 & 0 & 0 & 0 & 0 & 0 & 0 & 0 & 0 & 0 & 0 & 0 \\
\hline
\end{tabular}

Fertilizer Prescription Equations under IPNS for desired yield target

\begin{tabular}{|c|c|c|}
\hline Nutrients & With $\mathrm{OM}$ & Without OM \\
\hline $\mathbf{N}=$ & $3.56 \mathrm{~T}-0.60 \mathrm{SN}-2.82 \mathrm{ON}$ & $3.56 \mathrm{~T}-0.60 \mathrm{SN}$ \\
\hline $\mathrm{P}_{2} \mathrm{O}_{5}=$ & $0.51 \mathrm{~T}-3.30 \mathrm{SP}-2.88 \mathrm{OP}$ & $0.51 \mathrm{~T}-3.30 \mathrm{SP}$ \\
\hline $\mathrm{K}_{2} \mathrm{O}=$ & $0.71 \mathrm{~T}-0.12 \mathrm{SK}-1.81 \mathrm{OK}$ & $0.71 \mathrm{~T}-0.12 \mathrm{SK}$ \\
\hline
\end{tabular}

Where, $\mathrm{FN}, \mathrm{FP}_{2} \mathrm{O}_{5}$ and $\mathrm{FK}_{2} \mathrm{O}$ are fertilizer $\mathrm{N}$, $\mathrm{P}_{2} \mathrm{O}_{5}$ and $\mathrm{K}_{2} \mathrm{O}$ in $\mathrm{kg} \mathrm{ha}^{-1}$ respectively; $\mathrm{T}$ is the yield target in $\mathrm{t} \mathrm{ha}{ }^{-1}$; $\mathrm{SN}, \mathrm{SP}$ and $\mathrm{SK}$, respectively are alkaline $\mathrm{KMnO}_{4}-\mathrm{N}$, Bray-P and $\mathrm{NH}_{4} \mathrm{OAc}-\mathrm{K}$ in $\mathrm{kg} \mathrm{ha}^{-1}$ in soil. ON, OP and $\mathrm{OK}$ are the quantities of $\mathrm{N}, \mathrm{P}$ and $\mathrm{K}$ supplied through organic manure in $\mathrm{kg} \mathrm{ha}^{-1}$. Using the above equations, ready reckoners were 
formulated for a range of soil test values and desired yield targets (25 and $30 \mathrm{t} \mathrm{ha}^{-1}$ ) of brinjal with chemical fertilizers alone as well as in combination with organic manure @ $20 \mathrm{t}$ ha $^{-1}$ (Table 3).

The above furnished data evidently indicated that the fertilizer $\mathrm{N}, \mathrm{P}_{2} \mathrm{O}_{5}$ and $\mathrm{K}_{2} \mathrm{O}$ requirements decreased with increase in soil test values of $\mathrm{N}, \mathrm{P}$ and $\mathrm{K}$. Also the data obviously revealed that no need to apply any chemical fertilizers under IPNS system. For the soil test values of 100: 6: $100 \mathrm{~kg} \mathrm{ha}^{-1}$ of $\mathrm{KMnO}_{4}-\mathrm{N}$, Bray-P and $\mathrm{NH}_{4} \mathrm{OAc}-\mathrm{K}$, the quantity of fertilizer $\mathrm{N}, \mathrm{P}_{2} \mathrm{O}_{5}$ and $\mathrm{K}_{2} \mathrm{O}$ doses required for an yield target of 25 and $30 \mathrm{t} \mathrm{ha}^{-1}$ was 29,0 and $5.75 \mathrm{~kg} \mathrm{ha}^{-1}$ and 46.8, 0 and 9.3 $\mathrm{kg} \mathrm{ha}{ }^{-1}$ respectively. This necessitates the need for soil test based fertilizer prescription for relatively low nutrient exhaustive crops which can help the farmers to optimize the profit per return of rupee invested (Table 4).

Use of integrated plant nutrient management system (IPNS) resulted in saving of fertilizer nutrients in brinjal. Target yield equations generated from STCR - IPNS technology ensures not only sustainable crop production but also economic use of costly fertilizer inputs.

\section{Acknowledgements}

The authors express sincere thanks to Indian Council of Agricultural Research, New Delhi and Kerala Agricultural University, Thrissur for funding AICRP-STCR.

\section{References}

Package of Practices and Recommendations for crops, 2007. Kerala Agricultural University, Thrissur.

Piper, C. S. 1966. Soil and Plant Analysis. Hans Publications, Bombay.

Ramamoorthy, B., Narasimham, R. L. and Dinesh, R. S. 1967. Fertilizer application for specific yield targets on Sonora 64 (wheat). Indian Farming, 17: 43-45.

Santhi, R., Selvakumari, G. and Rani Perumal. 1999. Soil test based fertilizer recommendations under integrated plant nutrition system for rice-rice-pulse cropping sequence. J. Indian Soc. Soil Sci., 47: 288-294.

Sellamuthu, K. M., Santhi, R., Maragatham, S. and Dey, P. 2015. Balanced fertilizer prescription for glory lily through inductive cum- targeted yield model on an Alfisol. Res. Crops. 16 (3): 555-561.

\section{How to cite this article:}

Beena, V.I., B. Bastin, R.P. Raji Mol and Dey, P. 2018. Targeted Yield Based Fertilizer Prescriptions for Brinjal (Solanum melongena L.) in Ultisols of Kerala, India. Int.J.Curr.Microbiol.App.Sci. 7(10): 1235-1239. doi: https://doi.org/10.20546/ijcmas.2018.710.138 